Original Research

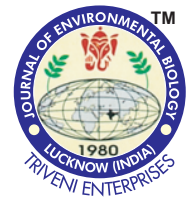

(1) (-)

\title{
The indicator plant species of wild animals in the Gidengelmez mountains district
}

Authors Info

H. SÜEL ${ }^{1 *}$, D. AKDEMIR ${ }^{2}$, A. KIRAÇ ${ }^{3}$ and $Y$. ÜNAL ${ }^{4}$

${ }^{1}$ Forestry Department, Sütçüler Vocational School, Suleyman Demirel University, Isparta, 32950, Turkey

${ }^{2}$ Forestry Department, Dursunbey, Vocational School, Balıkesir University, Isparta, 10800, Turkey ${ }^{3}$ Department of Wildlife Ecology and Management, Faculty of Forestry, Suleyman Demirel University, Isparta, 32100, Turkey ${ }^{4}$ Department of Wildlife Ecology and Management, Faculty of Forestry, Suleyman Demirel University, Isparta, 32100, Turkey

*Corresponding Author Email : halilsuel@sdu.edu.tr

\section{Key words}

Forest ecosystems, Indicator of habitat suitability, Mediterranean region, Wild animals

\section{Publication Info}

Paper received : 22.08.2016

Revised received : 25.06.2017

Accepted : 28.06.2017

\section{Abstract}

Aim : The present study was carried out to identify indicator plant species of wild animals in the Gidengelmez mountains district.

Methodology : The data was collected from 95 sample plots. Since all the data used were is binary, interspecific, correlation analysis was applied to examine the interrelationships between wild animals and plant taxa.

Results : It was found that the most important indicator plants of wild animals were Salvia tomentosa, Micromeria myrtifolia, Vicia cracca subsp. stenophylla, Arum dioscoridis var. spectabile, Rosa canina, Juniperus oxycedrus and Berberis crataegina. Vicia cracca subsp. stenophylla was the common indicator species for European hare (Lepus europaeus) and Badger (Meles meles), whereas Salvia tomentosa and Micromeria myrtifolia were significantly associated with Beech marten (Martes foina) and Red fox (Vulpes vulpes) The most important indicator plant for Wild boar (Sus scrofa) was Berberis crataegina. With regard to wild goat (Capra aegagrus) and brown bear (Ursus arctos), no plant was found to have strong indicatory value.

Interpretation : Correlation between occurrence and richness of wild animals and plant species richness was examined by Spearman correlation and Pearson correlation analysis. Among wild animals, only European hare was significantly related to plant species richness at the level of 0.05 . The relationship between wild animal richness and species richness was found insignificant.

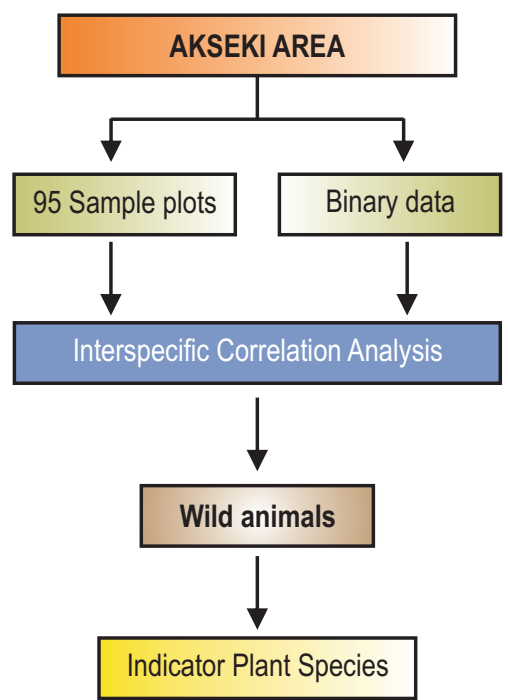




\section{Introduction}

Protection of wildlife and their habitats is the primary objective of natural resource management both for ecological and social reasons (Grimm, 1995; Decker et al., 2001; Morzillo et al., 2014). It is significant to have relevant information about biodiversity concepts for the protection of wild animals, ensuring continuation of their generation, and the species diversity (Aksan et al., 2014). It is essential to effectively use knowledge, experience and financial resources in order to manage wildlife resources. Therefore, the people interested in wildlife should be adequately trained for the effective use of resources and efficient, systematic and continuous plans (Bryan and Crossman, 2008). There are numerous approaches in order to obtain this information in a qualified manner (Westoby et al., 1989; McCann et al., 2006, Campomizzi et al., 2008; McRae et al., 2008; Phillips and Dudík, 2008). Most of these approaches reveal the need of wild animals by mainly comparing environmental variables (Johnson, 1980; Buckland and Elston, 1993; Boyce and McDonald, 1999).

Monitoring the change of natural resources in time is of great importance for the protection of wildlife. For this purpose natural degradation, human impact, management style, environmental factors and vegetation change need to be analyzed (Wisdom et al., 2002; Evers et al., 2011; Morzillo et al., 2012). The studies that include one or more of these factors can be regarded as reliable, practical and constant. It is known that wild animals are in connection with biotic and abiotic factors in the ecosystem and they are an indicator of ecosystem (Grimm, 1995; Bolen and Robinson, 1999; Miller and Eddleman, 2000; Connelly et al., 2004; Evers et al., 2011). Vegetation is one of the elements that has no monitoring unit and is focused regarding the wildlife studies. Therefore, it remains superficial in many studies. However, it is quite significant for wild animals to make plans based on vegetation characteristics and monitoring them in time (Morzillo et al., 2012). The reason is that vegetation changes based on environmental factors and it has an impact on wild animals.

Identifying the indicator species of wild animals, distribution of species, ecological conditions, and following the changes over time is very important (Atalay and Efe, 2015; Süel et al., 2013). The reason for this is that wild animals depend on plants for their needs of food, shelter, nesting, hiding and hunting (Bolen and Robinson, 1999; Oğurlu, 2016). Therefore, it can be concluded that vegetation is essential for each species, regardless of the type of feeding of wild animals.

In determining the indicator plant species of wild animals, interspecific correlation analysis is usually used. Özkan (2002) states that this analysis method has been by used by Holbrook (1979) and Shmida and Whittaker (1981) for assessing the relationship between plant species. Oğurlu and Aksan (2013) and Süel et al. (2013) conducted studies using interspecific correlation analysis about indicator plant species for wild animals, and reported successful results.

It is a known fact that the indicator species of both animals and plants in an area can be identified as positive and negative. Positive or negative relationship of the specific animals with plants can thus be predicted making use of indicator plant species in field inventory. Relationship between vegetation and the changes occurring in wild animals in time can be monitored. This study analyzes the relationship between wild animals and vegetation in Giden-Gelmez mountains located on the city borders of Antalya's Akseki town, and the results suggest a relationship between indicator plant species and species richness of wild animals.

\section{Materials and Methods}

Study area : The study area is located in Giden-Gelmez Mountains Mediterranean floristic region, which his in the northeast of Antalya at $37^{\circ} 17^{\prime} 16^{\prime \prime} \mathrm{N}$ latitude and $31^{\circ} 50^{\prime} 11^{\prime \prime} \mathrm{E}$ longitude. The area reaches about the boundaries of Akseki (Antalya) and Seydişehir (Konya) from south to north. In the western side of the area are located Bademli and Cevizli villages and Kuyucak mountain, while Ahırlı Village and Suğla Lake are located in the eastern part. In Seydişehir, which is in the north of the area, the total annual rainfall is around $447.7 \mathrm{~mm}$ and this figure is tripled in Akseki reaching up to $1355.5 \mathrm{~mm}$. The lowest altitude in the area is $1190 \mathrm{~m}$, while the highest altitute is $2370 \mathrm{~m}$, average altitude being around $1814 \mathrm{~m}$. In general, there is a transitional climate in the area varying from Mediterranean climate to terrestrial climate. Average rainfall during NovemberMarch is relatively more than during April, May, September and October. There is almost no rainfall during June-August. The lowest average temperatures are in December-February, and the highest average temperatures are in June-August (Özkan et al., 2014).

Data collection of plants and wild animals in study area : The inventory of wild animals for this study was prepared for 30 plots located inside the 95 sample areas in the dimensions of $100 \times 100$ $\mathrm{m}$. In each plot, feces, footprints and other signs and marks of animals were recorded. These records were identified with the help of contributor resources. Vegetation inventory prepared for these sample fields through Braun-Blanquet method, and plant species in these areas were identified. Quantal responses (1-0) of both plants and animals were marked.

Statistical analysis : Ninety eight plant taxa and five wild animal species (Table 1) were found during the study. These species were given codes in order to ease the statistical analysis procedure (Table 3$)$.

Interspecific correlation analysis was firstly conducted in this study in order to identify the correlation between wild animals and 98 plant species. Chi-square test was done through SPSS 
Table 1: Animal species and frequency percentages

\begin{tabular}{llllll}
\hline Species & Beech marten & European hare & Badger & Red fox & Wild boar \\
\hline Frequency (\%) & 20 & 44 & 12 & 17 & 59 \\
\hline
\end{tabular}

Table 2: C3 formula used for identifying the direction of the inter-species correlation

\begin{tabular}{lllll}
\hline & & Species A & \\
\cline { 3 - 5 } & & Presence & Absence & Total \\
\hline Species B & Presence & $a$ & $b$ & $a+b$ \\
& Absence & $c$ & $d$ & $c+d$ \\
& Total & $a+c$ & $b+d$ & $a+b+c+d$. \\
\hline
\end{tabular}

C3 formula: $\left[4^{*}(a d-b c)\right] /\left[(a+d)^{2}+(b+c)^{2}\right]$

20.0 software for analyzing data, and the direction of the relationship was identified using $\mathrm{C} 3$ formula based on this data. Calculations regarding the presence and abundance of wild animals and the presence of plant species were done using PAST software, and the correlations among them were analyzed by Spearman and Pearson correlation analysis.

Four figures $2 \times 2$ table was formed while calculating $\mathrm{C} 3$ coefficient in order to define the coefficient and direction of the correlation based on the quantal responses (Table 2). Then, C3 coefficients were identified using C3 formula (Cole, 1949; Özkan, 2002).

\section{Results and Discussion}

Chi-square $\left(x^{2}\right)$, significance level $(p)$ and correlation direction coefficients (C3), were obtained based on the interspecific correlation analysis used for wild animal species and plant species (Table 4).

AruDio (p:0.001), CloArb (p:0.001), QueLib (p:0.002), OnoAca (p:0.003), MicMyr (p:0.004), QueCoc (p:0.005) and SalTom (p:0.000) were found to be positive indicator species for the presence of beech marten. It is also understood that they prefered these species for nutrition.

VicCra (p:0.002), DiaZon (p:0.001), JunOxy (p:0.006), and SedCae (p:0.003) were positive indicator species for European hare. VicCra, DiaZon and SedCae species were used for nutrition, while JunOxy was used for the purposes of hiding and shelter.

While RosCan (p:0.000) and VicCra (p:0.001) were positive indicators for badger, VerOre (p:0.000) and DapOle ( $p: 0.002)$ were negative indicator species. Badger is known to be an omnivorous animal. This animal feeds on pieces of RosCan and VicCra and their fruits and it deserts the areas where VerOre and DapOle are found because VerOre and DapOle do not provide enough cover and limit its movement.
Although red fox is a carnivorous species, it behaves as an omnivorous animal in its nutrition habits. However, preference for nutrition was found in this study. MicMyr (p:0.008) and SalTom ( $p: 0.003$ ) are positive indicators for fox. It is also concluded that the red fox meets its nutrition and shelter needs through indirect methods. The negative indicator species of red fox was AcaUli ( $p: 0.005)$ because it didnot provide any food, shelter or hiding possibility. Common indicator species of European hare and badger is VicCra, while it is SalTom and MicMyr for beech marten and fox. It was also observed that common indicator plant species met different habitat demands of different animals.

BerCra (p:0.000), TriArv (p:0.003), and JunCom ( $p: 0.005)$ were positive indicator species for wild boar, and it uses these species for feeding. Wild boar feeds on both animal and plantal foods. In addition, AruDio (p:0.005), QueLib (p:0.000), and JunFoe ( $p: 0.008)$ were significant negative indicator species. It was found that the environment where AruDio and QueLib grow was not suitable for wild boar.

The correlations between the presence and abundance of wild animals and plant species richness were analyzed by Spearman and Pearson correlation analysis. While a correlation was found between wild animals and plant species richness, no correlation was found between wild animal presence and plant species richness.

As a result of the evaluation, it was found out that there was a correlation at 0.05 significance level only between European hare, out of all wild animals, and plant species richness. The correlation with plant species richness was found for the reasons of spread of European hare in quite diverse areas, various plant species involved its feeding, and meeting the cover demand of many different plants (Table 5).

The study area, located in the Central Taurus with its characteristics of the Taurus belt, consists of two terrestrial ecosystems of forest and subalpine (Özgül, 1997; Özkan et al., 
Table 3 : Plant names and codes used for statistical analysis

\begin{tabular}{|c|c|c|c|}
\hline Codes & Plant species & Codes & Plant species \\
\hline AbiCil & Abies cilicica (Ant. \& Kotschy) Carr. & NepNud & Nepeta nuda L. \\
\hline AcaUli & Acantholimon ulicinum (Willd. ex Schultes) Boiss. & OnoSpi & Ononis spinosa L. \\
\hline AceHyr & Acer hyrcanum Fisch. \& Mey. & OnoAca & Onopordum acanthium $\mathrm{L}$. \\
\hline AceMon & Acer monspessulanum $\mathrm{L}$. & OriSac & Origanum saccatum P. H. Davis \\
\hline AchBie & Achillea biebersteinii Afan. & OstCar & Ostrya carpinifolia Scop. \\
\hline AjuCha & Ajuga chamaepitys (L.) Schreber & PapPil & Papaver pilosum Sibth. \& SM. \\
\hline AllMyr & Allium myrianthum Boiss. & PelEnd & Pelargonium endlicherianum Fenzl \\
\hline AltOff & Althea officinalis $\mathrm{L}$. & PhIExa & Phleum exaratum Hochst. ex Griseb. \\
\hline AmePar & Amelanchier parviflora Boiss. & PhlArm & Phlomis armeniaca Willd. \\
\hline AntCre & Anthemis cretica subsp. tenuiloba (DC.) Grierson & PhlGra & Phlomis grandiflora H. S. Thompson \\
\hline AruDio & Arum dioscoridis var. spectabile (schott) Engl. & PhlSam & Phlomis samia L. \\
\hline AspAcu & Asparagus acutifolius $\mathrm{L}$. & PinNig & Pinus nigra J. F. Arnold \\
\hline AstMic & Astragalus microcephalus Willd. & PoaAng & Poa angustifolia L. \\
\hline BalGla & Ballota glandulosissima Hub.-Mor. \& Patzak & PopTre & Populus tremula L. \\
\hline BerCra & Berberis crataegina DC. & PruDiv & Prunus divaricata Ledeb. \\
\hline CapBur & Capsella bursa-pastoris (L.) Medik. & PyrEla & Pyrus elaeagnifolia Pallas \\
\hline CedLib & Cedrus libani A. Rich & QueCer & Quercus cerris L. \\
\hline CenUrv & Centaurea urvillei DC. & QueCoc & Quercus coccifera L. \\
\hline CirLau & Cistus laurifolius L. & QueLib & Quercus libani Olivier \\
\hline Clivul & Clinopodium vulgare $\mathrm{L}$. & RhaOle & Rhamnus oleoides $\mathrm{L}$. \\
\hline ColArb & Colutea arborescens $\mathrm{L}$. & RhaNit & Rhamnus nitidus Davis \\
\hline CraMon & Crataegus monogyna Jacq. & RhuCor & Rhus coriaria L. \\
\hline DacGlo & Dactylis glomerata L. & RosCan & Rosa canina L. \\
\hline DapOle & Daphne oleoides Schreber & RosPul & Rosa pulverulenta Bieb. \\
\hline DapSer & Daphne sericea Vahl & RubCan & Rubus canescens DC. \\
\hline DiaZon & Dianthus zonatus Fenzl & SalScl & Salvia sclarea L. \\
\hline DigDav & Digitalis davisiana Heywood & SalTom & Salvia tomentosa Miller \\
\hline DigFer & Digitalis ferruginea $\mathrm{L}$. & SamEbu & Sambucus ebulus L. \\
\hline DryPal & Dryopteris pallida (Bory) C.Chr. & ScoHis & Scolymus hispanicus L. \\
\hline EchVis & Echinops viscosus DC. & SedAlb & Sedum album $\mathrm{L}$. \\
\hline EryFal & Eryngium falcatum Delaroche. & SedCae & Sedum caespitosum (Cav.) DC. \\
\hline EupKot & Euphorbia kotschyana Fenzl & SidLib & Sideritis libanotica Labill. \\
\hline FerTra & Ferulago trachycarpa Boiss. & SidCon & Sideritis condensata Boiss. \\
\hline FibEri & Fibigia eriocarpa (DC.) Boiss. & SilAda & Silene adantopetala Fenzl \\
\hline FraOrn & Fraxinus ornus $\mathrm{L}$. & SorTor & Sorbus torminalis (L.) Crantz \\
\hline GalVer & Galium verum L. & SorUmb & Sorbus umbellata (Desf.) Fritsch \\
\hline HelAre & Helichrysum arenarium (L.) Mo & StyOff & Styrax officinalis L. \\
\hline HiePan & Hieracium pannosum Boiss. & Tellmp & Telephium imperati L. \\
\hline InuHet & Inula heterolepis Boiss. & LonNum & Lonicera nummularifolia Jaub. \& Spach \\
\hline JunCom & Juniperus communis subsp. nana Syme. & TeuCha & Teucrium chamaedrys $\mathrm{L}$. \\
\hline JunDru & Juniperus drupacea Lab. & TeuPol & Teucrium polium L. \\
\hline JunExc & Juniperus excelsa M. Bieb. & SatCun & Satureja cuneifolia Ten. \\
\hline JunFoe & Juniperus foetidissima Willd. & TriArv & Trifolium arvense $\mathrm{L}$. \\
\hline JunOxy & Juniperus oxycedrus L. & UlmGla & Ulmus glabra Hudson \\
\hline LamCar & Lamium cariense R. Mill & UrtDio & Urtica dioica L. \\
\hline LonEtr & Lonicera etrusca Santi & VerOre & Verbascum oreophilum C. Koch \\
\hline MarGlo & Marrubium globosum Montbret et Aucher ex Bentham & VerChe & Verbascum cheiranthifolium Boiss \\
\hline MelCli & Melica ciliata L. & VicCra & Vicia cracca L. subsp. stenophylla Vel. \\
\hline MicMyr & Micromeria myrtifolia Boiss. et Hohen. & XerCyl & Xeranthemum cylindraceum SM. \\
\hline
\end{tabular}


Table 4 : Indicator plant species for mammalian wildlife

\begin{tabular}{|c|c|c|c|c|c|c|c|c|c|c|c|c|c|c|c|c|}
\hline \multirow[t]{2}{*}{ No } & \multirow[t]{2}{*}{ Species classification } & \multicolumn{3}{|c|}{ Beech Marten } & \multicolumn{3}{|c|}{ European hare } & \multicolumn{3}{|c|}{ Badger } & \multicolumn{4}{|c|}{ Wild Boar } & \multicolumn{2}{|c|}{ Red fox } \\
\hline & & $x^{2}$ & $p$ & $\mathrm{C} 3$ & $x^{2}$ & $\mathrm{p}$ & C3 & $x^{2}$ & $p$ & C3 & $x^{2}$ & $\mathrm{p}$ & $\mathrm{C} 3$ & $x^{2}$ & $p$ & C3 \\
\hline$\overline{1}$ & AruDio & 10,200 & 0,001 & 0,236 & & & & & & & 14,775 & 0,005 & $-0,621$ & & & \\
\hline 2 & Cloarb & 10,200 & 0,001 & 0,236 & & & & & & & & & & & & \\
\hline 3 & QueLib & 9,500 & 0,002 & 0,444 & & & & & & & 12,403 & 0,000 & $-0,599$ & & & \\
\hline 4 & OnoAca & 8,741 & 0,003 & 0,313 & & & & & & & & & & & & \\
\hline 5 & MicMyr & 8,278 & 0,004 & 0,255 & & & & & & & & & & 6,964 & 0,008 & 0,216 \\
\hline 6 & QueCoc & 8,017 & 0,005 & 0,166 & & & & & & & & & & & & \\
\hline 7 & Saltom & 12,931 & 0,000 & 0,504 & & & & & & & & & & 8,072 & 0,003 & 0,390 \\
\hline 8 & Bercra & & & & & & & & & & 14,775 & 0,000 & 0,621 & & & \\
\hline 9 & TriArv & & & & & & & & & & 8,660 & 0,003 & 0,291 & & & \\
\hline 10 & JunCom & & & & & & & & & & 7,860 & 0,005 & 0,523 & & & \\
\hline 11 & JunFoe & & & & & & & & & & 6,591 & 0,008 & $-0,249$ & & & \\
\hline 12 & RosCan & & & & & & & 23,182 & 0,000 & 0,283 & & & & & & \\
\hline 13 & VerOre & & & & & & & 43,000 & 0,000 & $-0,204$ & & & & & & \\
\hline 14 & DapOle & & & & & & & 9,822 & 0,002 & $-0,342$ & & & & & & \\
\hline 15 & Viccra & & & & 9,444 & 0,002 & 0,435 & 10,782 & 0,001 & 0,232 & & & & & & \\
\hline 16 & DiaZon & & & & 10,311 & 0,001 & 0,529 & & & & & & & & & \\
\hline 17 & JunOxy & & & & 7,560 & 0,006 & 0,464 & & & & & & & & & \\
\hline 18 & SedCae & & & & 9,444 & 0,003 & 0,301 & & & & & & & & & \\
\hline 19 & AcaUli & & & & & & & & & & & & & 7,851 & 0,005 & $-0,423$ \\
\hline
\end{tabular}

Table 5 : Correlation coefficients between wild animals and plant species richness

\begin{tabular}{|c|c|c|c|c|c|c|}
\hline Species & & Beech marten & European hare & Badger & Wild boar & Red fox \\
\hline $\begin{array}{l}\text { Plant } \\
\text { species }\end{array}$ & Correlation coefficient & 0,061 & $0,251^{*}$ & 0,066 & 0,026 & 0,169 \\
\hline richness & Significance Level & 0,555 & 0,014 & 0,525 & 0,802 & 0,103 \\
\hline
\end{tabular}

2014). Most of the region reserve dolines and limestone pavement surfaced in carstic terrain is a unique feature of the area (Doğan, 2002). Considering all the characteristics of the area, it is seen that it has its own specific values and biodiversity. Therefore, many different plant indicator species were identified for wild animals. It was also concluded that many different factors impact on the analysis of these indicator species (Gülsoy and Özkan, 2013; Gülsoy et al., 2013, Negiz et al., 2015)

Berberis crataegina, Trifolium arvense and Juniperus communis are positive indicator species for wild boar, which is an omnivorous animal. These animals feed on fruits, shells, leaves, and trunks of these plants (Bratton, 1974; Schley and Roper, 2003; Herrero et al., 2006). The wild boar has a wide food preferences and especially likes fruit plants and prefers plants that are watery in summers and have dried fruits rich in fat in winters (Oğurlu and Aksan, 2013).

Arum dioscoridis var. spectabile, Quercus libani, and Juniper foemina are significant negative indicator species. It was observed that the environments where Arum dioscoridis var. spectabile and Quercus libani were present were not suitable for wild boars, because they prefer areas which enable them to hide and cover, and feed themselves with tuberous plants. Areas with no hiding cover, cliffs and slopes do not meet the preservation and feeding needs of this animal. Therefore, wild boars tend to live preferably in areas that provide hiding and covering needs and then feeding themselves in a proper way (Oğurlu, 2016; Süel et al., 2013).

The areas where indicator plants are found for European hare are forested and meet the covering and feeding needs of these animals. Forest communities are more in number in the field and the diversity of plant species is very high. These areas are preferred by European hare as they are rich in food. European hare eats Vicia cracca subsp. stenophylla, Dianthus zonatus and Sedum caespitosum (Reichlin et al., 2006; Karmiris and Nastis, 2010; Karmiris and Tsiouvaras, 2013; Freschi et al., 2015). European hare eats the leaves and the other parts of Vicia cracca subsp. stenophylla and Dianthus zonatus and eats whole of Sedum caespitosum. Despite the fact that European hare lives in relatively dense forest regions, located between $1500 \mathrm{~m}$ and $1670 \mathrm{~m}$, spoilt juniper areas with high diversity of plant species

and communities, forestation areas, and agricultural areas are most preferred habitat types (Oğurlu, 1997). The European hare 
generally prefers open habitats covered with vegetation (Peschel et al., 2011; Süel et al., 2013). This animal uses Juniperus oxycedrus for hiding and shelter purposes (Karmiris and Nastis, 2010).

Although beech marten is known to be a predator, feeding and hiding opportunities of plants play a key role in identifying habitat preferences (Virgos et al., 2010), it is an omnivorous animal. Plants, birds, and insects are in its food chain. Arum dioscoridis var. spectabile, Onopordum acanthium, Salvia tomentosa and Micromeria myrtifolia are known to be visited by many insects and the other creatures (Briese, 2006; Revel et al., 2012). Some plants are also known to be used for the treatment of animals (Viegi et al., 2003). Micromeria myrtifolia was used for this purpose for beech marten. Therefore, these indicator species are indirectly preferred for feeding purposes. Colutea arborescens, Quercus libaniand Quercus coccifera are preferred for both covering and feeding, because beech marten does not directly eat these species. However, it feeds on insects, birds and the other creatures (Süel et al., 2013). Additionally, beech marten feeds on bird eggs. In these cases, Quercus libani and Quercus coccifera, that can provide shelter for some bird species, are used as indicators (Herrero et al., 1981; Lopez and Moro, 1997).

While Rosa canina and Vicia cracca subsp. stenophylla are positive indicators for badger, Verbascum oreophilum and Daphne oleoides are negative indicator species. Badger especially eats fruits of Rosa canina and Vicia cracca subsp. stenophylla (Luís et al., 2009; Pamukoğlu and Albayrak, 2014). Ünal (2011) stated that badgers mainly prefers forest openings and forests. These fields are also suitable for badgers to dig. This is a significant reason for preference for badgers who feed by digging (Özen and Uluçay, 2010). The areas where fructus cynosbati and Vicia cracca subsp. stenophylla are available provide avenues for badger to dig. It avoids fields with Verbascum oreophilum and Daphne oleoides. The reason is that these species cannot provide enough cover and limit the mobility of badger (Süel et al., 2013).

Red fox is an omnivorous animal. In addition to the fact that there are some plants that feeds directly, there are also species that provide indirect food (Süel et al., 2013). Micromeria myrtifolia and Salvia tomentosa are useful for fox to feed indirectly; they also provide hiding and shelter for the animal. Acantholimon ulicinum is a negative indicator species because it limits the moving capability of fox and does not provide enough shelter. Therefore, red fox avoids fields where Acantholimon ulicinum grows.

Some indicator plant species have been identified for various wild animals in Giden-Gelmez Mountains. As a result of these findings, the existence of wild animals based on the plants

types found in the area can be predicted, and thereby some predictions regarding the vegetation that can affect the existence of which animals can be made. Thanks to this prediction, the study can be redirected, or the type, time and the other factors of the study can be modified, and better results could be obtained by better planning (Oğurlu and Aksan, 2013). Additionally, the changing conditions of wild animals can be tracked through the vegetation change. This means that environmental and anthropogenic influences on vegetation can be understood whether they affect wild animals or not, and early measures can be taken for conservation activities.

\section{Acknowledgments}

We thank National Parks General Directorate, VI. District Office of Ministry of Forestry and Water Management for their contributions to this study.

\section{References}

Aksan, Ş., I. Özdemir and İ. Oğurlu: Modeling the distributions of some wild mammalian species in Gölcük Natural Park. Turkey Biol. Divers. Conservat., 7, 1-15 (2014).

Atalay, İ. and R. Efe: Biogeography of Turkey (Türkiye Biyocoğrafyası). Meta Press, Izmir, Turkey (2015).

Bolen, E.G. and W.L. Robinson: Wildlife ecology and management, fourth edition. Upper Saddle River, NJ: Prentice Hall (1999).

Boyce, M.S. and L.L. McDonald: Relating populations to habitats using resource selection functions. Trends Ecol. Evol., 14, 268-272 (1999).

Bratton, S.P.: An integrated ecological approach to the management of the European wild boar (Sus scrofa) in Great Smoky Mountains National Park Report to the National Park Service. Mimeo., (1974).

Briese, D.: Can an apriori strategy be developed for biological control. The case of Onopordum spp. thistles in Australia. Aust. J. Entomol., 45, 317-323 (2006).

Bryan, B.A. and N.D. Crossman: Systematic regional planning for multiple objective natural resource management. J. Environ. Manag., 88, 1175-1189 (2008).

Buckland, S.T. and D.A. Elston: Empirical models for the spatial distribution of wildlife. J. Appl. Ecol., 30, 478-495(1993).

Campomizzi, A.J., J.A. Butcher, S.L. Farrell, A.G. Snelgrove, B.A. Collier, K.J. Gutzwiller, M.L. Morrison and R.N. Wilkins: Conspecific attraction is a missing component in wildlife habitat modeling. $J$. Wildl. Manag., 72, 331-336 (2008).

Cole, L.C.: The measurement of interspesific association. Ecology, 30, 411-424 (1949).

Connelly, J. W., S. T. Knick, M. A. Schroeder and S. J. Stiver: Conservation assessment of greater sage-grouse and sagebrush habitats. Cheyenne, Wyoming: Western Association of Fish and Wildlife Agencies. (2004).

Decker, D.J., T.L. Brown and W.F. Siemer: Human dimensions of wildlife management in North America. Bethesda, MD: The Wildlife Society. (2001).

Doğan, U.: Geomorphological evolution of the Manavgat River's basin. Gazi University J. Gazi Educational Faculty, 22, 51-65 (2002).

Evers, L., R.F. Miller, M. Hemstrom, J. Merzenich, R. Neilson and P. Doescher: Estimating historical sage-grouse habitat abundance using a state-and-transition model. Nat. Resour. Environ., 17, 117129 (2011). 
Freschi, P., S. Fascetti, M. Musto, E. Mallia, C. Cosentino and R. Paolino: Diet of the Italian hare (Lepus corsicanus) in a semi-natural landscape of southern Italy. Mammalia, 79, 51-59 (2015).

Grimm, N.B.: Why link species and ecosystems? A perspective from ecosystem ecology. In: Linking species and ecosystems (Eds.: C.G. Jones and J.H. Lawton). Chapman and Hall, New York (1995).

Gülsoy, S. and K. Özkan: Determination of environmental factors and indicator plant species for site suitability assessment of Crimean Juniper in the Acipayam District, Turkey. Sains Malaysiana, 42, 1449-1457 (2013).

Gülsoy, S., Ö. Şentürk and M.G. Negiz: Identification of indicatory plant species for target species by using quantitative methods: A case study from Acıpayam district. Turk. J. Fores., 14, 10-14 (2013).

Herrero, J., A. García-Serrano, S. Couto, V.M. Ortuño and R. GarcíaGonzález: Diet of wild boar Sus scrofa L. and crop damage in an intensive agroecosystem. Eur. J. Wildl. Res., 52, 245-250 (2006).

Holbrook, S. J.: Habitat utilization, competitive interactions and coexistence of three species of cricetine rodents in East-Central Arizona. Ecology, 60, 758-769 (1979).

Johnson, D.H.: The comparison of usage and availability measurements for evaluating resource preference. Ecology, 61, 65-71 (1980).

Karmiris, I. and A. Nastis: Diet overlap between small ruminants and the European hare in a Mediterranean shrubland. Cent. Eur. J. Biol., 5, 729-737 (2010).

Karmiris, I. And K. Tsiouvaras: Effects of several plant species on the spatial distribution of the European hare (Lepus europaeus) at the microhabitat scale. Dry Grasslands of Europe: Grazing and Ecosystem Services Proceedings of 9th European Dry Grassland Meeting (EDGM) Prespa, Greece, pp. 169-174 (2013).

Lopez, G. and M.J., Moro: Birds of Aleppo Pine Plantations in SouthEast Spain in relation to vegetation composition and structure. J. Appl. Ecol., 34, 1257-1272 (1997).

Luís, M., L.M. Rosalino and M. Santos-Reis: Fruit consumption by carnivores in Mediterranean Europe. Mamm. Rev., 39, 67-78 (2009).

McCann, R.K., B.G. Marcot and R. Ellis: Bayesian belief networks: Applications in ecology and natural resource management. Can. J. Forest. Res., 36, 3053-3062 (2006).

McRae, B.H., N.H. Schumaker, R.B. McKane, R.T. Busing, A.M. Solomon and C.A. Burdick:A multi-model framework for simulating wildlife population response to land-use and climate change. Ecol. Model., 219, 77-91 (2008).

Miller, R.F. and L. Eddleman: Spatial and temporal changes in sage grouse habitat in the sagebrush biome. Tech. Bull. 151. Corvallis, Oregon: Oregon State University; Agricultural Experiment Station, USA(2000).

Morzillo, A.T., P. Comeleo, B. Csuti and S. Lee: Application of state-andtransition models to evaluate wild life habitat. US Forest Service General Technical Report. Pages 129-145 in Halofsky, J. E., Creutzburg, M.K., \& Hemstrom, M. A., (technical editors). Integrating social, economic, and ecological values across large landscapes. Pacific Northwest Research Station General Technical Report PNW-GTR-896. Portland, OR:USDA Forest Service, (2014).

Morzillo, A.T., J.S. Halofsky, J. DiMiceli and M. Hemstrom: Balancing feasibility and precision of wildlife habitat analysis in planning for natural resources. In: Proceedings of the first landscape stateand-transition simulation modeling conference (Eds.: B.K. Kerns,
A. Shlisky and C. Daniel). Gen. Tech. Rep. PNW-GTR-869. Portland, OR: U.S. Department of Agriculture, Forest Service, Pacific Northwest Research Station: 103-114 (2012).

Negiz, M.G., Y., Eser, E., Kuzugüdenli and K. Özkan: Indicator species of essential forest tree species in the Burdur district. J. Environ. Biol., Special issue, 36,107-111 (2015).

Oğurlu, I.: Habitat Use and Food Habits of Brown Hare (Lepus europaeus (Pallas)) in a Woodland. Turkish J. Zoology, 21, 381-398 (1997).

Oğurlu, İ.: Wildlife Ecology (Yaban Hayatı Ekolojisi). Süleyman Demirel University Press, Isparta, Turkey (2016).

Oğurlu, İ. and Ş. Aksan: Determination of indicator woody plant species for potential habitats of some wild mammalian species. SDU Faculty of Forestry J., 14, 81-87 (2013).

Özen, A.S. and I. Uluçay: Ecological, biological And taxonomical characteristics of Meles meles Linnaeus, 1758 (Mammalia: Carnivora) In Kütahya. J. Instit. Sci. Technol. Dumlupınar University, 21, 9-20 (2010).

Özgül, N.: Stratigraphy of The Tectonostratigraphic Units Around HadimBozkir-Taşkent Region (Northern Part of The Central Taurides, Turkey). Bull. Mineral Res. Explor., 119, 113-174 (1997).

Özkan, K.: The measurement of interspecific association by interspecific correlation analysis. SDU Faculty of Forestry J., 2, 71-78 (2002).

Özkan, K., H. Fakir, Y. Ünal, A. Baygal, V. A. Karacan and R. Aygün: Antalya Cevizli Gidengelmez Mountain Wildlife Development Area Management and Development Plan (Antalya Cevizli Gidengelmez Dağı Yaban Hayatı Geliştirme Sahası Yönetim Ve Gelişme Planı). Ministry of Forest and Water Affairs, General Directorate of Nature Conservation and National Parks, pp. 156 (2014).

Pamukoğlu, N. and İ. Albayrak: The Taxonomy and Ecology of Meles meles (L., 1758) in Western Turkey. Hacettepe J. Biol. Chem., 42(4), 451-458 (2014).

Peschel, U., S. Fuchs, N. Klar and C.C. Voigt: Home range and habitat use of the brown hare (Lepus europaeus) on organic farmland, Bundesamt für Naturschutz (Bfn) - Federal Agency for Nature Conservation, German (2011).

Phillips, S.J. and M. Dudík: Modeling of species distributions with Maxent: New extensions and a comprehensive evaluation. Ecography, 31, 161-175(2008).

Reichlin, T., E. Klansek and K. Hackländer: Diet selection by hares (Lepus europaeus) in arable land and its implications for habitat management. Eur. J. Wildl. Res., 522, 109-118 (2006).

Revel, N., N. Alvarez, M. Gibernau and A. Espindola: Investigating the relationship between pollination strategies and the size-advantage model in zoophilous plants using the reproductive biology of Arum cylindraceum and other European Arum species as case studies. Arthropod-Plant Interactions, 6, 35-44 (2012).

Schley, L. and T. J. Roper: Diet of wild boar Sus scrofa in Western Europe, with particular reference to consumption of agricultural crops. Mamm. Rev., 33, 43-53 (2003).

Shmida, A. and R. H. Whittaker: Pattern and biological microsite effects in two shrub communities, Southern California. Ecology, 62, 234251 (1981).

Süel, H., E.T. Ertuğrul, Ş. Aksan, Y. Ünal, D. Akdemir, G. Cengiz, H. Bayrak, M.Ö. Ersin, İ. Oğurlu, K. Özkan and İ. Özdemir: Indicator species of habitat preferences to wildlife animals in Köprüçay district. 3rd International Geography Symposium, p. 553 (2013).

Viegi, L., A. Pieroni, P.M. Guarrera and R. Vangelisti: A review of plants used in folk veterinary medicine in ltaly as basis for a databank. $\mathrm{J}$. Ethnopharmacol., 89, 221-44 (2003). 
Virgos, E., S. Cabezas-Díaz, J. G. Mangas and J. Lozano: Spatial distribution models in a frugivorous carnivore, the stone marten (Martes foina): Is the fleshy-fruit availability a useful predictor?. Animal Biology, 60, 423-436 (2010).

Westoby, M., B. Walker and I. Noy-Meir: Opportunistic management for rangelands not at equilibrium. J. Rangeland Manag., 42, 266-274
(1989).

Wisdom, M.J., M.M. Rowland, B.C. Wales, M.A. Hemstrom, W.J. Hann, M.G. Raphael, R.S. Holthausen, R.A. Gravenmier and T.D. Rich: Modeled effects of sagebrush-steppe restoration on Greater sagegrouse in the Interior Columbia Basin, U.S.A. Conservat. Biol., 16, 1223-1231 (2002). 